\title{
A review on the book "Leonid Rubtsov - a prominent landscape architect" by O. L. Rubtsova and N. V. Chuvikina
}

\section{(1) Yurii Klymenko}

M.M. Gryshko National Botanical Garden, National Academy of Sciences of Ukraine, Tymiryazevska str. 1, 01014 Kyiv, Ukraine; klimenco109@ukr.net

\begin{abstract}
A monograph devoted to the life and work of the outstanding landscape architect Leonid Ivanovich Rubtsov has been recently published. The book provides information about the projects developed and implemented by professor Rubtsov, as well as the main theoretical principles of landscape architecture, which were proposed by him.
\end{abstract}

Keywords: L.I. Rubtsov, biography, botanical garden, landscape architecture, dendrology

Funding: No fundings were declared.

Competing Interests: The author declared no conflict of interest.

A monograph "Leonid Rubtsov - a prominent landscape architect" of O.L. Rubtsova and N.V. Chuvikina (224 pages) has been published by the Phoenix publishing house in Kyiv in 2021 (Fig. 1).

The monograph is dedicated to the life and creative activity of the prominent landscape architect, doctor of biological sciences, professor Leonid Ivanovich Rubtsov. Leonid Ivanovich designed and, most importantly, implemented significant number of projects. Most of the implemented projects became classic examples of landscape architecture. For example, the Lilac garden at the M.M. Gryshko National Botanical Garden of the National Academy of Sciences of Ukraine is one of the signature landmarks of Kyiv. That is why the life story of this talented, versatile person is a matter of great interest for those engaged in dendrology, floriculture, landscape architecture, urban greenery, breeding, and adjacent disciplines.

The peculiarity of the book is that the reader can learn not only what and when Leonid Ivanovich did, but also immerse in the atmosphere of each stage of his life. Including the atmosphere of the historical events in the country and the tasks set for domestic biologists that created a background of the life story of professor Rubtsov at different periods. The book also contains brief biographical information of outstanding mentors who shared their knowledge with Leonid Ivanovich during his study, prominent scientists, and heads of institutions where L.I. Rubtsov worked, his friends and colleagues, as well as students who became famous figures in domestic science.

Another feature of the book is that talking about L.I. Rubtsov's expeditions, books, and 


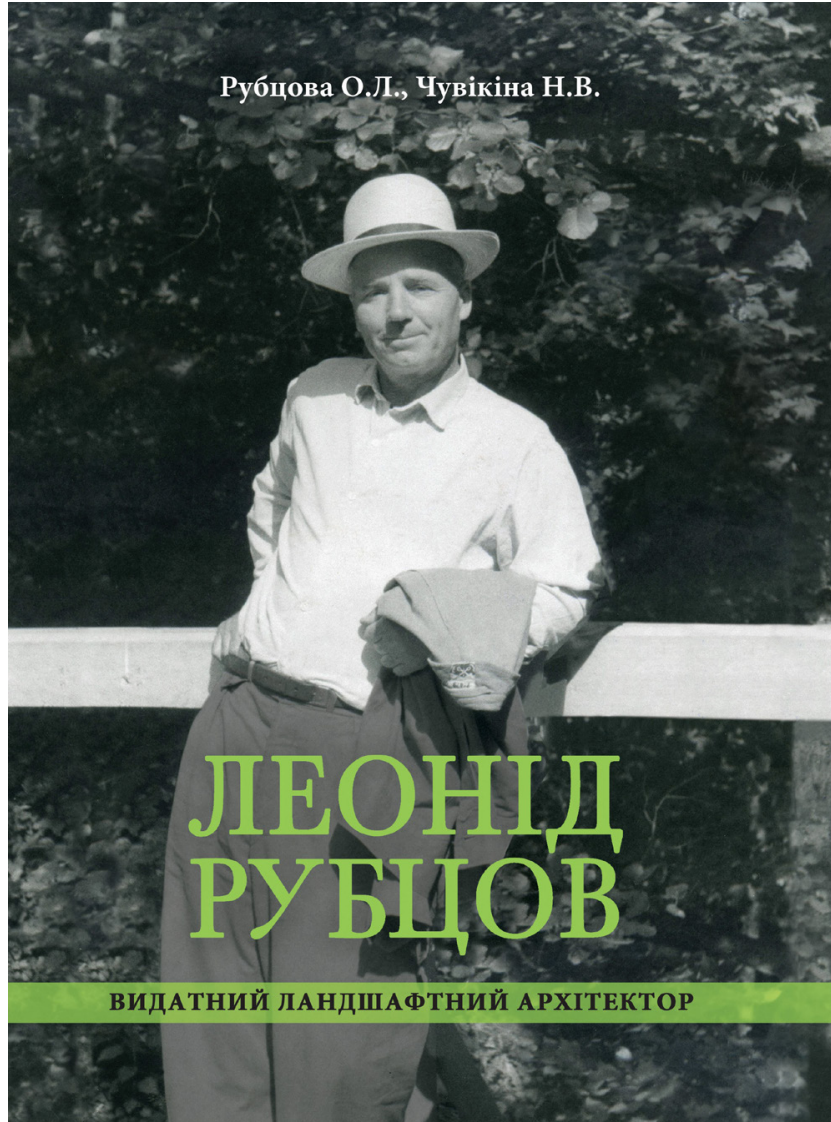

Figure 1. The cover of the book "Leonid Rubtsov - a prominent landscape architect".

projects, the authors provide information about parks and botanical gardens, which he surveyed, explain the basic theoretical principles, and show how these principles were implemented in specific conditions of particular projects. Thus, a careful reading of the monograph allows readers to acquaint themselves with multiple theses of landscape architecture, especially those formulated by Leonid Ivanovich.

Classification of physiognomic types of woody plants developed by L.I. Rubtsov helped many landscape architects who had a purely architectural education to address issues related to the selection of species for creation of the plantations. His classification of types of gardens and parks' landscapes is the best fitted for landscape analysis of territories.

The book is beautifully illustrated with photographs of different years, drawings, sketches. There are many photos of Leonid Ivanovich with colleagues, photos of centuriesold trees (longevity of trees was one of the topics studied by L.I. Rubtsov), different parts of the botanical garden, etc. For those who know the M.M. Gryshko National Botanical Garden well, it will be interesting to find the places where some photos were taken and compare them with their current appearance.

The monograph includes a complete list of L.I. Rubtsov's published works, as well as his certificates (with coauthors) for derived varieties of lilacs.

Once again, the book reminds us about the necessity to keep the heritage of the person who formed the appearance of a large part of the M.M. Gryshko National Botanical Garden. Everything should be done here to preserve and develop the scientific and landscape components of the arboretum, to implement the ideas of L.I. Rubtsov, which remained as design drafts.

\section{Рецензія на книгу “Леонід Рубцов - видатний ландшафтний архітектор" О.Л. Рубцової та Н.В. Чувікіної}

Юрій Клименко

Національний ботанічний сад ім. М.М. Гришка НАН України, вул. Тимірязєвська 1, Київ, 01014, Україна; klimenco109@ukr.net

Вийшла друком монографія, присвячена життю та творчій діяльності видатного ландшафтного архітектора Леоніда Івановича Рубцова. У книзі наведена інформація про розроблені та реалізовані професором Рубцовим проекти, а також основні теоретичні положення ландшафтної архітектури, які вінзапропонував. 